\title{
15. BOLBOFORMA (CHRYSOPHYTA?) FROM THE WESTERN NORTH ATLANTIC ${ }^{1}$
}

\author{
C. Wylie Poag and A. L. Karowe, U.S. Geological Survey, Woods Hole ${ }^{2}$
}

\begin{abstract}
From 10 localities along the western margin of the North Atlantic Ocean, including Deep Sea Drilling Project (DSDP) Sites 106, 604, and 612, we have observed 11 species of presumed encysted calcareous algae assignable to the genus Bolboforma Daniels and Spiegler. These microfossils range stratigraphically from the upper Eocene to the Pliocene in this region and are found in inner sublittoral $(30-50 \mathrm{~m})$ to abyssal $(4500 \mathrm{~m})$ paleodepths. A transect from the Virginia Coastal Plain across the adjacent continental shelf to the abyssal plain indicates that bathyal sites contain the richest assemblages. Large populations from our samples reveal that variability in exterior morphology in conjunction with differential calcite dissolution may confuse taxonomic assignments and lead to false stratigraphic assumptions. We believe that careful analysis and comparison of large populations will lead to the widespread application of Bolboforma to interregional and global problems of biostratigraphy, paleoecology, and paleobiogeography.
\end{abstract}

\section{INTRODUCTION}

The genus Bolboforma was introduced in 1974 to accommodate 11 species of calcareous, lagenoid microfossils (74-200 $\mu \mathrm{m}$ diameter), having protozoan or algal affinities, recovered from upper Oligocene to upper Miocene marine sedimentary rocks of northwest Germany (Fig. 1; Daniels and Spiegler, 1974). Subsequently, 13 papers have documented Bolboforma from additional localities, including several DSDP coring sites (Table 1). Five additional species have been described, the stratigraphic range has been extended downward to the upper Eocene and upward to the upper Pliocene, and the geographic distribution has been extended from the eastern North Atlantic into the western North Atlantic and the western South Pacific (Rögl and Hochuli, 1976; Willems, 1976; Odrzywalska-Bieńkowa, 1976; Bizon et al., 1977; Murray, 1979, 1984; Doppert, 1980; Daniels et al., 1981; Szczechura, 1982; King, 1983; Müller et al., 1985; Echols, 1985; Poag and Karowe, 1986).

After 10 years of study, the biological classification of the genus Bolboforma is still uncertain, although a growing consensus suggests they are cysts of algae related to the chrysophytes (e.g., Tappan, 1980). Regardless of their biological nature, however, Bolboforma exhibit several characteristics that promise utility for stratigraphy, paleoecology, and paleobiogeographic interpretation: test morphology is variable and distinctive enough to allow differentiation of "species"; stratigraphic ranges are relatively short (on the order of a few million years); specimens often occur in large numbers (thousands) in small samples; and the group appears to have been planktonic, having species that are geographically widespread. Of special importance is a relatively high resistivity to carbonate dissolution, which allows the preservation of abundant $\mathrm{Bol}$ boforma in samples where other calcareous remains,

\footnotetext{
${ }^{1}$ Poag, C. W., Watts, A. B., et al., Init Repts. DSDP, 95: Washington (U.S. Govt. Printing Office).

2 Addresses: (Poag) U.S. Geological Survey, Woods Hole, MA 02543; (Karowe) Woods Hole Oceanographic Institution, Woods Hole, MA 02543.
}

such as foraminifers, are sparse or absent (Müller et al., 1985; Poag and Karowe, 1986). Furthermore, the richest assemblages, both in numbers of specimens and numbers of species, are concentrated on submerged continental margins, where much research and exploration is currently being carried out (Poag and Karowe, 1986).

We have previously reported (Poag and Karowe, 1986) several species of Bolboforma from DSDP sites and other boreholes along the United States Atlantic margin, including Sites 612 and 604 of the New Jersey Transect. In this chapter, we discuss those findings in more detail and illustrate important morphologic and microstructural characteristics of taxonomic and possibly paleoenvironmental significance.

\section{DISTRIBUTION OF BOLBOFORMA IN THE WESTERN NORTH ATLANTIC REGION}

We have recovered assemblages of Bolboforma from three DSDP sites (106B, 604, and 612), two ASP (Atlantic Slope Project; Poag, 1978) sites (15 and 22), two Continental Offshore Stratigraphic Test wells (COST B-2 and B-3), and three coastal plain sites (a borehole near Haynesville, Virginia and two outcrops in eastern Wayne County, Mississippi; Figs. 1, 2, 3; Poag and Karowe, 1986). A total of 11 species are recognized in this region (Fig. 3; Plates 1-4), four of which are unnamed (they will be formally described and named in a separate publication).

Assemblages containing the most abundant specimens and species come from the bathyal sites (COST B-3, DSDP 612,613 ); their numbers diminish both shoreward (COST B-2, Haynesville corehole) and basinward (DSDP 106; Fig. 3). Similar abundance maxima are seen in bathyal sites on the eastern margin of the North Atlantic (Poag and Karowe, 1986). This distribution pattern suggests that Bolboforma preferred a bathyal habitat during its testate stage, perhaps influenced by the high fertility of slope water masses. The Haynesville, Virginia, corehole represents the shallowest paleoenvironment (inner shelf 30-50 m depth) in which we have found $\mathrm{Bol}$ boforma (Poag and Karowe, 1986), and DSDP Site 106 is the deepest site $(4500 \mathrm{~m})$ from which Bolboforma has 


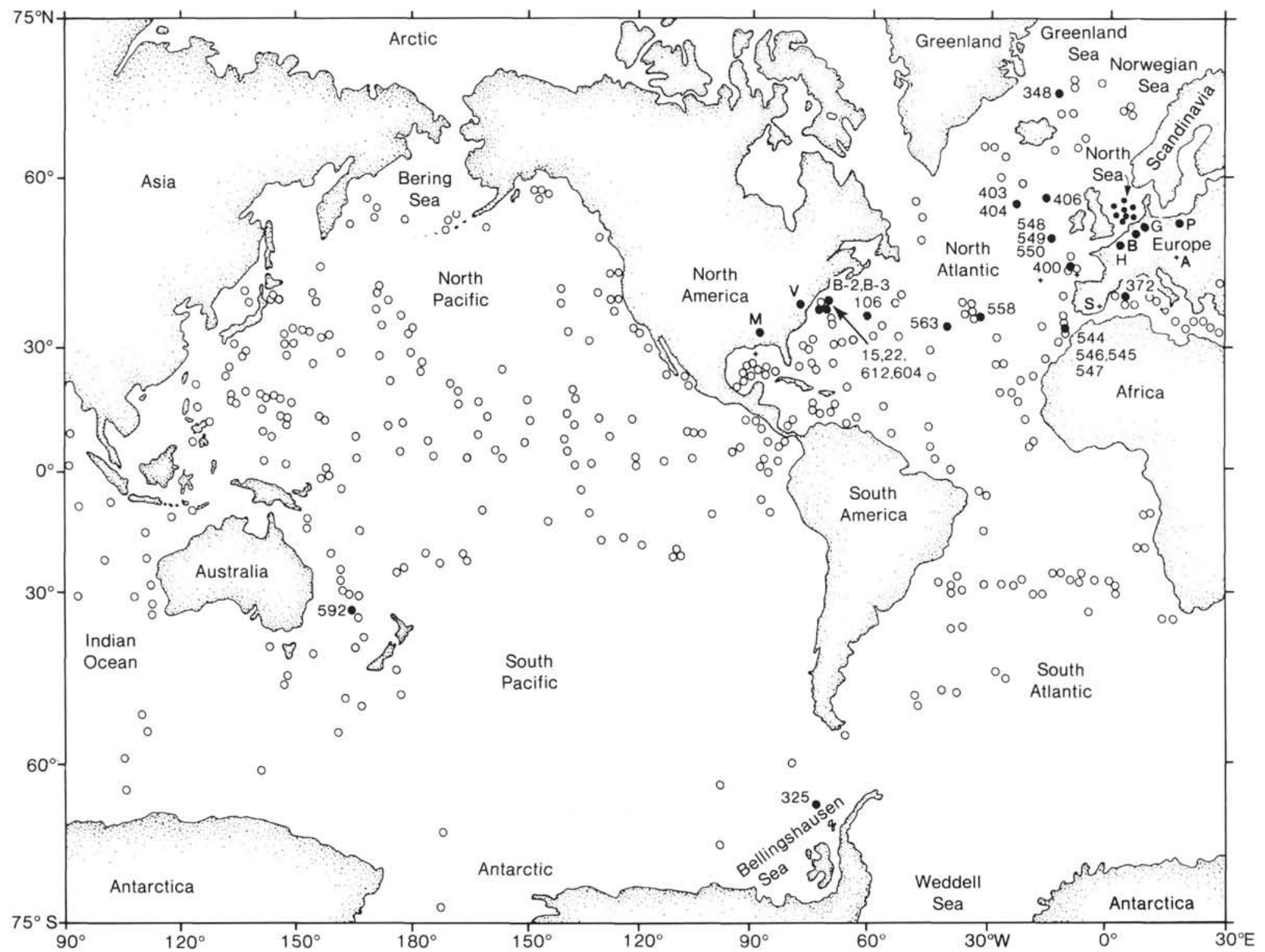

Figure 1. Map of presently known distribution of the genus Bolboforma. Numbered solid circles indicate sites where Bolboforma has been documented by published data; crosses indicate sites where Bolboforma has been reported as being present, but not otherwise documented (personal communication, etc.); open circles indicate Deep Sea Drilling Project boreholes from which Bolboforma has not been reported. Letters indicate localities on land: $\mathrm{M}=\mathrm{Mississippi} ; \mathrm{V}=\mathrm{Virginia} ; \mathrm{B}=\mathrm{Belgium}$ (Willems, 1976; Müller et al., 1985); $G=$ northwest Germany (Daniels and Spiegler, 1974); $\mathrm{P}=$ Poland (Odrzywolska-Bieńkowa, 1976; Szczechura, 1982); A = Austria (Müller et al., 1985); S = Spain (Bizon et al., 1977); H = Holland (Doppert, 1980). Wells in the North Sea are too numerous to show exact locations (King, 1983). 
Table 1. Global distribution of Bolboforma.

\begin{tabular}{|c|c|c|c|c|c|}
\hline Region & $\begin{array}{l}\text { Sample } \\
\text { source }\end{array}$ & Location & Reference & $\begin{array}{l}\text { No. of } \\
\text { species }\end{array}$ & $\begin{array}{l}\text { Total } \\
\text { strat. } \\
\text { range }\end{array}$ \\
\hline Austria & Unspecified & Vienna Basin & 6,10 & ? & ? \\
\hline Belgium & Unspecified & Near Antwerp & 13 & 6 & $\begin{array}{l}\text { upper } \\
\text { Miocene }\end{array}$ \\
\hline Germany & $\begin{array}{l}\text { Several } \\
\text { boreholes }\end{array}$ & Near Hamburg & 2 & 11 & $\begin{array}{l}\text { upper Olig.- } \\
\text { upper Mio. }\end{array}$ \\
\hline Holland & $\begin{array}{l}\text { Several } \\
\text { boreholes }\end{array}$ & Unspecified & 3 & 2 & $\begin{array}{l}\text { middle Mio.- } \\
\text { upper Mio. }\end{array}$ \\
\hline Poland & $\begin{array}{l}\text { Several } \\
\text { outcrops }\end{array}$ & $\begin{array}{l}\text { Near Roztocze } \\
\text { and Kikó }\end{array}$ & 9,11 & 3 & $\begin{array}{l}\text { middle } \\
\text { Miocene }\end{array}$ \\
\hline Spain & Unspecified & Near Alicante & 1 & 1 & $\begin{array}{l}\text { middle } \\
\text { Miocene }\end{array}$ \\
\hline Mississippi & Outcrop? & Unspecified & 12 & 2 & $\begin{array}{l}\text { lower } \\
\text { Oligocene }\end{array}$ \\
\hline Mississippi & 2 Outcrops & $\begin{array}{l}\text { N.E. Wayne } \\
\text { County }\end{array}$ & 14 & 2 & $\begin{array}{l}\text { lower } \\
\text { Oligocene }\end{array}$ \\
\hline Virginia & $\begin{array}{c}\text { Coastal plain } \\
\text { borehole }\end{array}$ & $\begin{array}{l}37^{\circ} 57.22 \cdot \mathrm{N} \\
76^{\circ} 40.43^{\prime} \mathrm{W}\end{array}$ & 14 & 4 & $\begin{array}{l}\text { upper Olig.- } \\
\text { middle Mio. }\end{array}$ \\
\hline $\begin{array}{l}\text { Gulf of } \\
\text { Mexico }\end{array}$ & $\begin{array}{l}\text { Outer shelf } \\
\text { borehole }\end{array}$ & Unspecified & 14 & 2 & $\begin{array}{l}\text { middle } \\
\text { Miocene }\end{array}$ \\
\hline North Sea & $100-200$ wells & Unspecified & 5 & 4 & $\begin{array}{l}\text { middle Mio.- } \\
\text { upper Mio. }\end{array}$ \\
\hline Mediterranean & DSDP 372 & $\begin{array}{l}40^{\circ} 01.86^{\prime} \mathrm{N} \\
04^{\circ} 47.79^{\prime} \mathrm{E}\end{array}$ & 1 & 2 & $\begin{array}{l}\text { middle } \\
\text { Miocene }\end{array}$ \\
\hline $\begin{array}{l}\text { Eastern N. } \\
\text { Atlantic }\end{array}$ & DSDP 119 & $\begin{array}{l}45^{\circ} 01.90^{\prime} \mathrm{N} \\
07^{\circ} 58.49^{\prime} \mathrm{W}\end{array}$ & 8 & 2 & $\begin{array}{l}\text { middle Mio.- } \\
\text { upper Mio. }\end{array}$ \\
\hline $\begin{array}{l}\text { Eastern } \mathrm{N} . \\
\text { Atlantic }\end{array}$ & DSDP 348 & $\begin{array}{l}68^{\circ} 30.18^{\prime} \mathrm{N} \\
12^{\circ} 27.72^{\prime} \mathrm{W}\end{array}$ & 6 & 1 & $\begin{array}{l}\text { lower } \\
\text { Miocene }\end{array}$ \\
\hline $\begin{array}{l}\text { Eastern N. } \\
\text { Atlantic }\end{array}$ & DSDP 400 & $\begin{array}{l}47^{\circ} 22.90^{\prime} \mathrm{N} \\
09^{\prime \prime} 11.90^{\prime} \mathrm{W}\end{array}$ & 6 & 4 & $\begin{array}{l}\text { middle Mio.- } \\
\text { upper Mio. }\end{array}$ \\
\hline $\begin{array}{l}\text { Eastern N. } \\
\text { Allantic }\end{array}$ & DSDP 403 & $\begin{array}{l}56^{\circ} 08.31^{\prime} \mathrm{N} \\
23^{\circ} 17.64^{\prime} \mathrm{W}\end{array}$ & 7 & 2 & $\begin{array}{l}\text { upper } \\
\text { Miocene }\end{array}$ \\
\hline $\begin{array}{l}\text { Eastern N. } \\
\text { Atlantic }\end{array}$ & DSDP 404 & $\begin{array}{l}56^{\circ} 03.13^{\prime} \mathrm{N} \\
23^{\circ} 14.95^{\prime} \mathrm{W}\end{array}$ & 7 & 5 & $\begin{array}{l}\text { upper } \\
\text { Miocene }\end{array}$ \\
\hline $\begin{array}{l}\text { Eastern N. } \\
\text { Atlantic }\end{array}$ & DSDP 406 & $\begin{array}{l}55^{\circ} 15.50^{\prime} \mathrm{N} \\
22^{\circ} 05.41^{\prime} \mathrm{W}\end{array}$ & 7 & 4 & $\begin{array}{l}\text { upper } \\
\text { Miocene }\end{array}$ \\
\hline $\begin{array}{l}\text { Eastern N. } \\
\text { Allantic }\end{array}$ & DSDP 544 & $\begin{array}{l}33^{\circ} 46.00^{\prime} \mathrm{N} \\
09^{\circ} 24.30^{\prime} \mathrm{W}\end{array}$ & 14 & 5 & $\begin{array}{l}\text { middle Mio.- } \\
\text { upper Mio. }\end{array}$ \\
\hline $\begin{array}{l}\text { Eastern N. } \\
\text { Atlantic }\end{array}$ & DSDP 545 & $\begin{array}{l}33^{\circ} 46.00^{\prime} \mathrm{N} \\
09^{\circ} 24.30^{\prime} \mathrm{W}\end{array}$ & 14 & 4 & $\begin{array}{l}\text { middle } \\
\text { Miocene }\end{array}$ \\
\hline $\begin{array}{l}\text { Eastern N. } \\
\text { Atlantic }\end{array}$ & DSDP 546 & $\begin{array}{l}33^{\circ} 46.71^{\prime} \mathrm{N} \\
09^{\circ} 33.86^{\prime} \mathrm{W}\end{array}$ & 14 & 11 & $\begin{array}{l}\text { middle Mio.- } \\
\text { upper Plio. }\end{array}$ \\
\hline $\begin{array}{l}\text { Eastern N. } \\
\text { Atlantic }\end{array}$ & DSDP 547 & $\begin{array}{l}33^{\circ} 46.84^{\prime} \mathrm{N} \\
09^{\circ} 20.98^{\prime} \mathrm{W}\end{array}$ & 14 & 9 & $\begin{array}{l}\text { lower Mio.- } \\
\text { upper Mio. }\end{array}$ \\
\hline $\begin{array}{l}\text { Eastern N. } \\
\text { Atlantic }\end{array}$ & DSDP 548 & $\begin{array}{l}48^{\circ} 54.95 ' \mathrm{~N} \\
12^{\circ} 09.84^{\prime} \mathrm{W}\end{array}$ & 14 & 4 & $\begin{array}{l}\text { upper } \\
\text { Miocene }\end{array}$ \\
\hline $\begin{array}{l}\text { Eastern } \mathrm{N} \text {. } \\
\text { Atlantic }\end{array}$ & DSDP 549 & $\begin{array}{l}49^{\circ} 05.28^{\prime} \mathrm{N} \\
13^{\circ} 05.88^{\prime} \mathrm{W}\end{array}$ & 14 & 6 & $\begin{array}{l}\text { upper Eo.- } \\
\text { upper Mio. }\end{array}$ \\
\hline $\begin{array}{l}\text { Eastern N. } \\
\text { Atlantic }\end{array}$ & DSDP 550 & $\begin{array}{l}48^{\circ} 30.91^{\prime} \mathrm{N} \\
13^{\circ} 26.37^{\prime} \mathrm{W}\end{array}$ & 6,14 & 13 & $\begin{array}{l}\text { lower Mio.- } \\
\text { upper Mio. }\end{array}$ \\
\hline $\begin{array}{l}\text { Eastern N. } \\
\text { Atlantic }\end{array}$ & DSDP 552 & $\begin{array}{l}56^{\circ} 02.56^{\prime} \mathrm{N} \\
23^{\circ} 13.88^{\prime} \mathrm{W}\end{array}$ & 8 & 8 & $\begin{array}{l}\text { middle Mio.- } \\
\text { upper Plio. }\end{array}$ \\
\hline $\begin{array}{l}\text { Eastern N. } \\
\text { Atlantic }\end{array}$ & DSDP 553 & $\begin{array}{l}56^{\circ} 05.32^{\prime} \mathrm{N} \\
23^{\circ} 20.61^{\prime} \mathrm{W}\end{array}$ & 8 & 6 & $\begin{array}{l}\text { lower Mio.- } \\
\text { upper Mio. }\end{array}$ \\
\hline $\begin{array}{l}\text { Eastern N. } \\
\text { Atlantic }\end{array}$ & DSDP 554 & $\begin{array}{l}56^{\circ} 17.41^{\prime} \mathrm{N} \\
23^{\circ} 31.69^{\prime} \mathrm{W}\end{array}$ & 8 & 6 & $\begin{array}{l}\text { middle Mio.- } \\
\text { upper Mio. }\end{array}$ \\
\hline $\begin{array}{l}\text { Eastern N. } \\
\text { Atlantic }\end{array}$ & DSDP 555 & $\begin{array}{l}56^{\circ} 33.70^{\prime} \mathrm{N} \\
20^{\circ} 46.93^{\prime} \mathrm{W}\end{array}$ & 8 & 7 & $\begin{array}{l}\text { middle Mio.- } \\
\text { upper Mio. }\end{array}$ \\
\hline $\begin{array}{l}\text { Central N. } \\
\text { Atlantic }\end{array}$ & DSDP 558 & $\begin{array}{l}37^{\circ} 46.20^{\prime} \mathrm{N} \\
37^{\circ} 20.61^{\prime} \mathrm{W}\end{array}$ & 4 & 4 & $\begin{array}{l}\text { middle } \\
\text { Miocene }\end{array}$ \\
\hline $\begin{array}{l}\text { Central N. } \\
\text { Atlantic }\end{array}$ & DSDP 563 & $\begin{array}{l}33^{\circ} 38.53^{\prime} \mathrm{N} \\
43^{\circ} 46.04^{\prime} \mathrm{W}\end{array}$ & 4 & 4 & $\begin{array}{l}\text { middle } \\
\text { Miocene }\end{array}$ \\
\hline $\begin{array}{l}\text { Western N. } \\
\text { Atlantic }\end{array}$ & COST B-2 & $\begin{array}{l}39^{\circ} 22.50^{\prime} \mathrm{N} \\
72^{\circ} 44.00^{\prime} \mathrm{W}\end{array}$ & 14 & 2 & $\begin{array}{l}\text { upper } \\
\text { Eocene }\end{array}$ \\
\hline $\begin{array}{l}\text { Western N. } \\
\text { Atlantic }\end{array}$ & Cost B-3 & $\begin{array}{l}38^{\circ} 55.00^{\prime} \mathrm{N} \\
72^{\circ} 46.40^{\prime} \mathrm{W}\end{array}$ & 14 & 4 & $\begin{array}{l}\text { upper Eo.- } \\
\text { middle Mio. }\end{array}$ \\
\hline $\begin{array}{l}\text { Western N. } \\
\text { Atlantic }\end{array}$ & ASP 15 & $\begin{array}{l}38^{\circ} 46.30^{\prime} \mathrm{N} \\
72^{\circ} 48.30^{\prime} \mathrm{W}\end{array}$ & 14 & 2 & $\begin{array}{l}\text { lower Olig.- } \\
\text { middle Mio. }\end{array}$ \\
\hline $\begin{array}{l}\text { Western N. } \\
\text { Atlantic }\end{array}$ & ASP 22 & $\begin{array}{l}37^{\circ} 02.50^{\prime} \mathrm{N} \\
74^{\circ} 32.90^{\prime} \mathrm{W}\end{array}$ & 14 & 2 & $\begin{array}{l}\text { upper } \\
\text { Oligocene }\end{array}$ \\
\hline $\begin{array}{l}\text { Western N. } \\
\text { Atlantic }\end{array}$ & DSDP 106 & $\begin{array}{l}36^{\circ} 26.01^{\prime} \mathrm{N} \\
69^{\circ} 27.69^{\prime} \mathrm{W}\end{array}$ & 14 & 2 & $\begin{array}{l}\text { middle } \\
\text { Miocene }\end{array}$ \\
\hline $\begin{array}{l}\text { Western N. } \\
\text { Atlantic }\end{array}$ & DSDP 604 & $\begin{array}{l}38^{\circ} 43.10^{\prime} \mathrm{N} \\
72^{\circ} 33.60^{\prime} \mathrm{W}\end{array}$ & 14 & 6 & $\begin{array}{l}\text { upper Mio.- } \\
\text { upper Plio. }\end{array}$ \\
\hline $\begin{array}{l}\text { Western N. } \\
\text { Atlantic }\end{array}$ & DSDP 612 & $\begin{array}{l}38^{\circ} 49.21 \cdot \mathrm{N} \\
72^{\circ} 46.43^{\prime} \mathrm{W}\end{array}$ & 14 & 5 & $\begin{array}{l}\text { upper Eo.- } \\
\text { upper Mio. }\end{array}$ \\
\hline Antarctic & DSDP 325 & $\begin{array}{l}65^{\circ} 02.79^{\prime} \mathrm{S} \\
73^{\circ} 40.40^{\prime} \mathrm{W}\end{array}$ & 10 & 5 & $\begin{array}{l}\text { lower } \\
\text { Miocene }\end{array}$ \\
\hline $\begin{array}{l}\text { Western S. } \\
\text { Pacific }\end{array}$ & DSDP 592 & $\begin{array}{l}36^{\circ} 28.40^{\prime} \mathrm{S} \\
165^{\circ} 26.53^{\prime} \mathrm{E}\end{array}$ & 14 & 8 & $\begin{array}{l}\text { upper Eo.- } \\
\text { upper Mio. }\end{array}$ \\
\hline
\end{tabular}

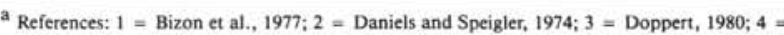

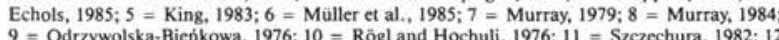
= Tappan, 1980; 13 = Willems, 1976; 14 = Poag and Karowe, 1986, and this chapter.

been reported. The findings reported here incorporate the entire documented record of Bolboforma in the western North Atlantic.

Bolboforma ranges stratigraphically from the upper Eocene (COST B-2, B-3, DSDP 612) to the Pliocene

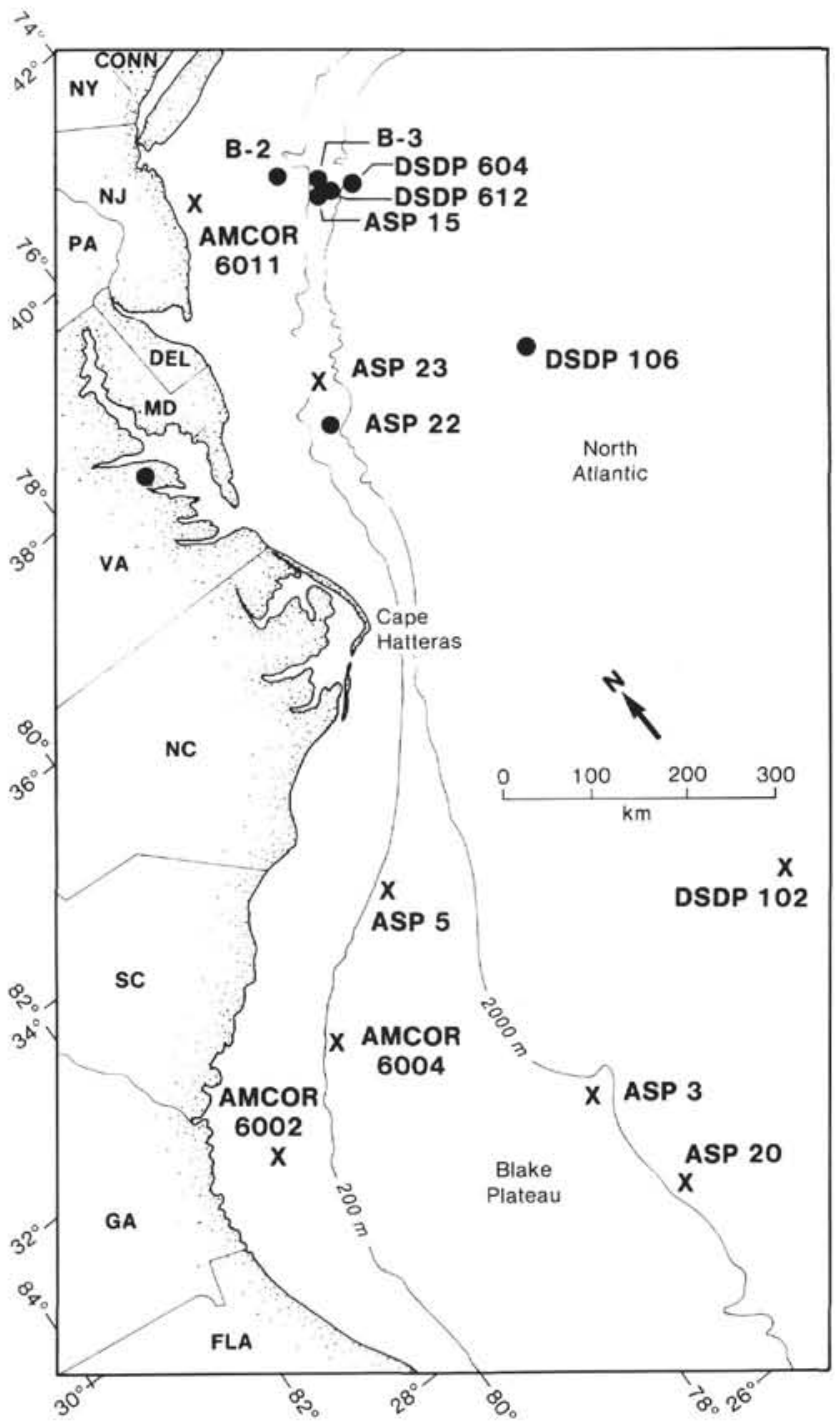

Figure 2. Map of U.S. Atlantic margin sites examined by us for the presence of Bolboforma; crosses indicate that appropriate stratigraphic section is present, but Bolboforma was not observed. AMCOR = Atlantic Margin Coring Project (Hathaway et al., 1979); ASP $=$ Atlantic Slope Project (Poag, 1978); COST = Continental Offshore Stratigraphic Test (Scholle, 1980); DSDP = Deep Sea Drilling Project.

(DSDP 604) in our study area and is most abundant (specimens and species) in the lower Oligocene and upper Miocene sections. Its presence, however, is sporadic at some sites, such as ASP 15, where all calcareous microfossils are poorly preserved in glauconitic sands and diatom-radiolarian muds.

\section{TEST MORPHOLOGY AND INTRASPECIFIC VARIABILITY}

As a consequence of the richness and good preservation of much of our sample material, we obtained a large number of scanning electron microscope (SEM) photomicrographs to analyze the test morphology of Bolboforma. The following discussion is somewhat preliminary because we have not yet achieved the same degree of knowledge regarding the rich assemblages from the 


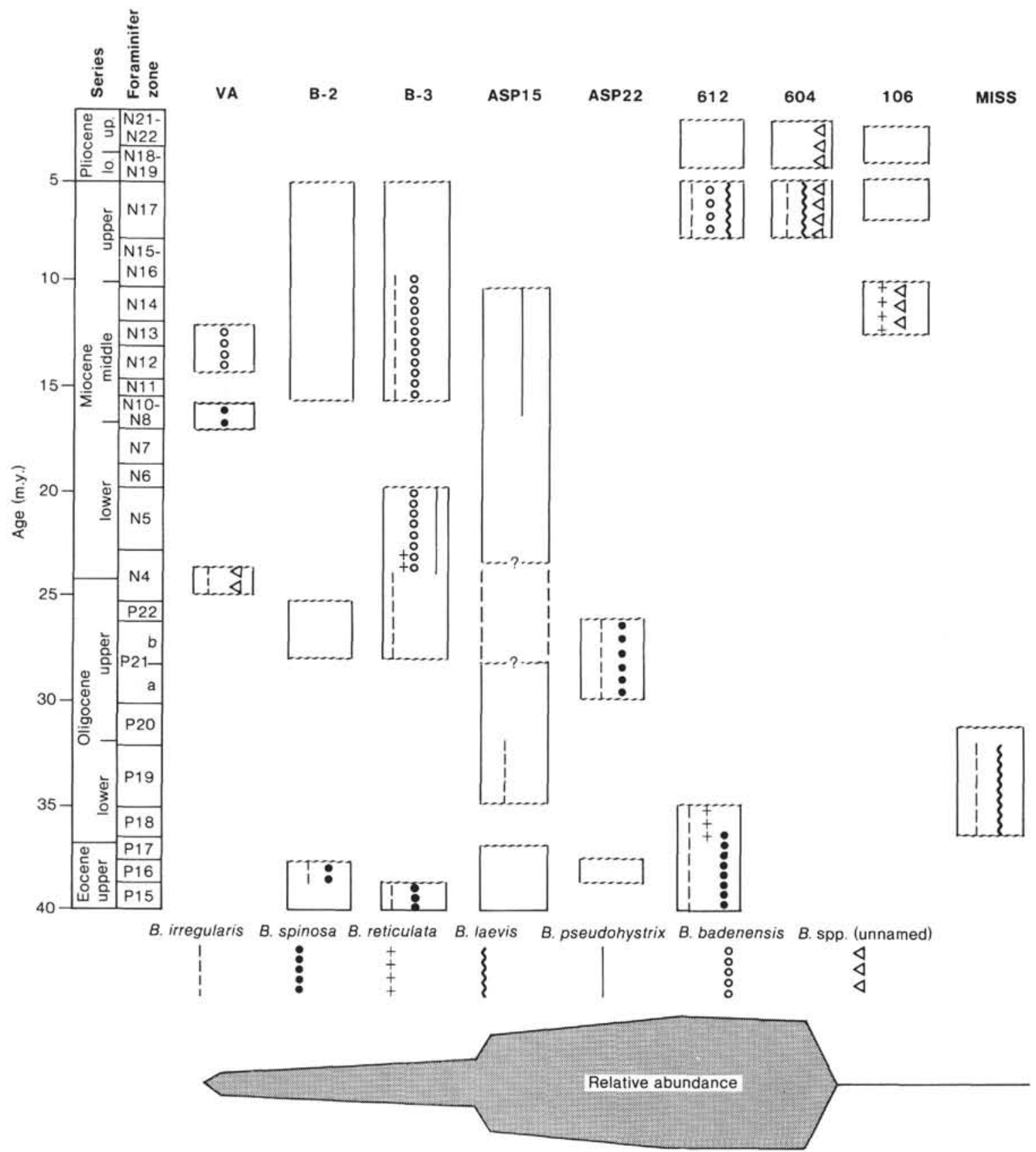

Figure 3. Stratigraphic distribution of Bolboforma species in the U.S. Atlantic and Gulf coast sections.

eastern North Atlantic and the western South Pacific. We believe, however, that our current findings will point out avenues for future research and will help stabilize the taxonomy and systematics of this poorly known group of microfossils.

\section{General Morphology}

Two typical types of Bolboforma tests are currently known: (1) a monocamerate type composed of a single globose (or subglobose) hollow chamber of calcite (e.g., Pl. 1, Figs. 1-3, 5, 6, 9-16). This type has in addition, a short protruding neck (Pl. 1, Figs. 1-3) containing a circular aperture and a tubular channel that connects to the chamber lumen. The tubular channel is normally sep- arated from the chamber lumen by a thin calcite plate that contains a circular central pore (Pl. 1, Fig 5); (2) a bicamerate type composed of two hollow calcite chambers (often of unequal diameter) either joined tangentially (Pl. 1, Figs. 4, 7, 8; Daniels et al., 1981) or having the second chamber envelop the first (Pl. 2, Figs 10-12; Poag and Karowe, 1986). In tangentially joined bicamerate tests, the chambers are often separated by a thin calcite plate that contains a circular pore (Pl. 1, Figs. 7, 8). A variety of spines, ridges, blades, and reticulations provide a wide range of external ornamentation (Poag and Karowe, 1986). We have found a few specimens of both types of bicamerate tests in the western North Atlantic, but the majority of specimens by far are monocamerate. 


\section{Chamber Shape}

In their original paper, Daniels and Spiegler (1974) described two general chamber shapes to which they assigned specific taxonomic value: (1) a spherical or subspherical shape (not counting the protruding neck) and (2) a subspherical shape having a distinctly flattened aboral surface. Several subsequent authors have noted that a single species may display considerable variability between spherical and flattened tests (e.g., Willems, 1976). Our investigations corroborate these findings and suggest further that the test shape of almost every species of Bolboforma can vary from spherical to ablong to aborally flattened. In other words, test shape per se appears to be a poor criterion for separating forms of $\mathrm{Bol}$ boforma at the species level (see, e.g., Pl. 1, Figs. 1-6; Pl. 2, Figs 4-8; Pl. 3, Figs 7-16). However, some assemblages tend to be predominantly either spherical or flattened, depending perhaps upon environmental conditions or the relative position within an evolving lineage.

\section{Exterior Ornamentation}

We (Poag and Karowe, 1986) listed several types of general surface ornamentation, such as reticulation, among the species observed to date. A variety of each type of ornamentation has been used to separate different species. For example, B. metzmacheri has finer reticulations than $B$. reticulata (Daniels and Spiegler, 1974; Poag and Karowe, 1986). We believe, however, that several different species have been assigned to $B$. metzmacheri by various authors on the basis of different perceptions of the variability among types of reticulation. For example, the $B$. metzmacheri of Odrzwolska-Bieńkowa (1976, pls. 1 and 2) appears to us to be $B$. reticulata of Daniels and Spiegler (1974) and Müller et al. (1985). On the other hand, B. reticulata of Murray (1984; pl. 1, figs. 11,12 ) appears to be either $B$. intermedia of Daniels and Spiegler (1974) or an unnamed species.

Among the spinose types of Bolboforma, the two species $B$. clodiusi and $B$. spinosa were originally distinguished by assigning specimens having flattened aboral surfaces to B. clodiusi. However, we have observed a strong tendency in western Atlantic "spinosa" to be less densely spinose (like the holotype of B. spinosa) than other specimens illustrated from the eastern North Atlantic (e.g., Müller et al., 1985; pl. 1, figs. 14, 16, 18). Further study of large populations from many localities is necessary to establish more reliably the limits of intraspecific morphologic variability within all the taxa of Bolboforma.

\section{THE EFFECT OF CALCITE DISSOLUTION ON TAXONOMIC INTERPRETATION}

We have found that calcite dissolution, whether contemporaneous with or following deposition, can modify the surface texture of some forms of Bolboforma so dramatically as to disguise one species as another. One of the most striking examples is illustrated in Plate 2 (Figs. 4-9). A series of specimens of B. metzmacheri from DSDP Site 604 underwent progressive dissolution that transformed a strongly reticulate form into a smoothsurfaced form resembling $B$. laevis. A faint impression of the reticulate pattern remains in Figure 9, but it cannot be distinguished by examining specimens under an optical microscope. Thus one must take special care in assigning slightly roughened, but otherwise smooth specimens to B. laevis. For example, the specimens of Bizon et al., (1976, pl. 1, figs. 1, 2) and of Rögl and Hochuli (1977, pl. 1, fig. 12) were assigned to B. laevis, but we suspect that they may be partly dissolved specimens of originally more ornate species.

Another example is shown in Plate 4, Figures 8-10. Here corroded specimens of $B$. irregularis have lost most of the reticulate ornamentation, retaining chiefly a few of the spines that originally arose from the reticulae. Under an optical microscope it would be difficult to recognize such specimens as $B$. irregularis.

The combined results of morphologic variability and differential calcite dissolution can thus lead to serious mistakes in species identification, as is already apparent in the literature. Such confusion, however, is difficult to eliminate at this early stage in the study of Bolboforma, because so few populations have been rigorously studied and compared. These problems must be solved before the stratigraphic and paleoenvironmental implications of Bolboforma can be applied on an interregional and global scale, although the group has already been quite useful in local stratigraphic studies (e.g., Doppert, 1980; King, 1983).

\section{WALL STRUCTURE OF THE BOLBOFORMA TEST}

A complete description and analysis of wall microstructure among Bolboforma is beyond the scope of this chapter, yet we have observed several important aspects of construction that should be recorded and illustrated at this time. Daniels and Spiegler (1974), Rögl and Hochuli (1976) and Müller et al. (1985) reported that Bolboforma specimens studied by them appeared to have tests composed of a single calcite crystal (optically monocrystalline). Little attention has been paid to microstructural aspects by other authors. Our studies, however, show that the wall structure of some species is much more complex than that of a single calcite crystal. The wall of $B$. metzmacheri and B. irregularis, for example, is composed of at least three layers of calcite. A thin external layer forms the reticulae and spines (Pl. 2, Figs. 7, 8; Pl. 4, Figs. 6-12), which are separated by hollow spaces from the underlying middle layer. The middle layer is thicker and often of spongy texture (Pl. 4, Fig. 12). A third (inner) layer is thinner (like the outer layer) and comprises the inner surface of the test. The third layer is especially evident as the inner surface of the tubular neck (e.g., PI. 3 , Fig. 4).

The internal wall surface of well-preserved specimens of $B$. irregularis displays faint broad troughs that ring the test in a direction perpendicular to the oral axis. However, upon dissolution, this inner surface becomes spongy (Pl. 4, Figs. 4, 5). The middle? calcite layer of specimens of B. laevis (Pl. 1, Figs. 1-6) and B. sp. (Pl. 2, 
Figs. 10, 12), when etched, shows a peculiar arrangement of several adjacent circular whorls of tabular crystallites.

Much additional analysis using thin sections and transmission and scanning electron microscopy is needed to satisfactorily elucidate the detailed microstructure of Bolboforma.

\section{SUMMARY AND CONCLUSIONS}

We have identified assemblages of Bolboforma from seven offshore boreholes and three coastal plain localities along the western margin of the North Atlantic Ocean. Eleven species are present, including four new unnamed species. Bolboforma ranges from the upper Eocene to the Pliocene in this region, but is most abundant in lower Oligocene and middle Miocene sections. Richest assemblages come from the bathyal sites; numbers of species and specimens diminish in sublittoral and abyssal environments. Microstructural and dissolution features described and illustrated here demonstrate that Bolboforma is a more complex group of organisms than originally thought, requiring much further study (especially of large populations) and comparison of assemblages from many localities. We believe that given adequate study, Bolboforma will prove to be quite useful for biostratigraphic, biogeographic, and paleoenvironmental research on an interregional and global scale.

\section{ACKNOWLEDGMENTS}

We are grateful to Judith Commeau for providing the scanning electron photomicrographs and to Doris Low for assisting with the extraction and sorting of specimens. Robert Mixon, James May, and Page C. Valentine were instrumental in obtaining samples from the coastal plain localities. Alfred R. Loeblich, Jr. and Dorothy Echols kindly reviewed an early version of the manuscript.

\section{REFERENCES}

Bizon, G., Taugourdeau-Lantz, J., and Wright, R., 1977. Présence d'Algues enkystées: Pachysphaera et de microfossiles d'affinités incertaines: Bolboforma dans le Miocene de Méditerranée. Rev. Micropaleontol., 20:140-146.

Daniels, C. H. von, and Spiegler, D., 1974. Bolboforma n. gen. (Protozoa?) - eine neue stratigraphisch wichtige Gattung aus dem Oligozän/Miozän Nordwestdeutschlands. Palaont. Zeits., 48:57-76.

Daniels, C. H. von, Spiegler, D., and Bijvank, G., 1981. Zweikammerige Bolboforma (Mikroproblematica, Protozoa?). Palaont. Zeits., 55:175-177.
Doppert, J. W. C., 1980. Lithostratigraphy and biostratigraphy of marine Neogene deposits in the Netherlands. Meded. Rijks Geol. Dienst, 32-16:255-311.

Echols, D., 1985. "Bolboforma," a Miocene algae(?) of possible biostratigraphic and paleoclimatic value. In Bougault, $\mathrm{H}$., Cande, S. C., et al., Init. Repts. DSDP, 82: Washington (U.S. Govt. Printing Office), 605-610.

Hathaway, J. C., Poag, C. W., Valentine, P. C., Miller, R. E., Schultz, D. M., Manheim, F. T., Kohout, F. A., Bothner, M. H., and Sangree, D. A., 1979. U.S. Geological Survey core drilling on the Atlantic Shelf. Science, 206:515-527.

King, C., 1983. Cainozoic micropaleontological biostratigraphy of the North Sea. Rept. Inst. Geol. Sci., 82/7:1-40.

Müller, C., Spiegler, D., and Pastouret, L., 1985. The genus Bolbofor$m a$ Daniels and Spiegler in the Oligocene and Miocene sediments of the North Atlantic and northern Europe. In Graciansky, P. C. de, Poag, C. W., et al., Init. Repts. of DSDP, 80, Pt. 1: Washington (U.S. Govt. Printing Office), 669-675.

Murray, J. W., 1979. Cenozoic biostratigraphy and paleoecology of Sites 403 to 406 based on the foraminifers. In Montadert, L., Roberts, D. G., et al., Init. Repts. DSDP, 48: Washington, (U.S. Govt. Printing Office), 415-430. , 1984. Biostratigraphic value of Bolboforma, Leg 81, Rockall Plateau. In Roberts, D. G., Schnitker, D., et al., Init. Repts. DSDP, 81: Washington (U.S. Govt. Printing Office), 535-539.

Odrzywolska-Bieńkowa, E., 1976. O niektórych gatunkach z rodzaju Bolboforma (Protozoa?) w miocenie Polski. Kwart. Geol., 20:551560.

Poag, C. W., 1978. Stratigraphy of the Atlantic Continental Shelf and Slope of the United States. Ann. Rev. Earth Planet. Sci., 6:251280.

Poag, C. W., and Karowe, A. L., 1986. Stratigraphic potential of Bolboforma significantly increased by new finds in the North Atlantic and South Pacific. Palaios, 1:162-171.

Rögl, F., and Hochuli, P., 1976. The occurrence of Bolboforma, a probable algal cyst, in the Antarctic Miocene of DSDP Leg 35. In Hollister, C. D., Craddock, C., et al., Init. Repts DSDP, 35: Washington (U.S. Govt. Printing Office), 713-719.

Scholle, P. A. (Ed.), 1980. Geological studies of the COST No. B-3, well, United States Mid-Atlantic Continental Slope areas. U.S. Geol. Surv. Circ., 833:1-132.

Szczechura, J., 1982. Middle Miocene foraminiferal biochronology and ecology of SE Poland. Acta Paleont. Polonica, 27:3-60.

Tappan, H., 1980. The Paleobiology of Plant Protists: San Francisco, (W. H. Freeman), p. 509.

Willems, W., 1976. The genus Bolboforma von Daniels and Spiegler in the upper Miocene of northern Belgium. Bull. Soc. Belge Géol., 85:31-38.

Date of Initial Receipt: 8 October 1985

Date of Acceptance: 28 June 1986 


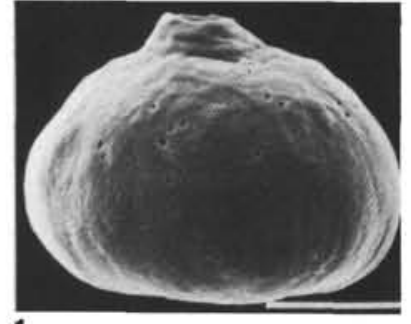

1

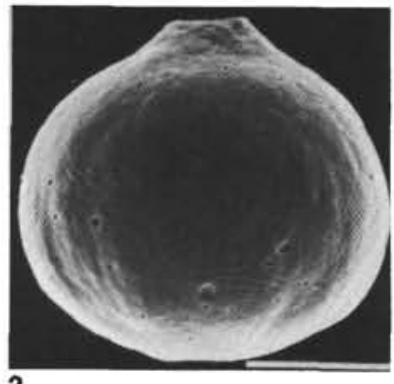

2

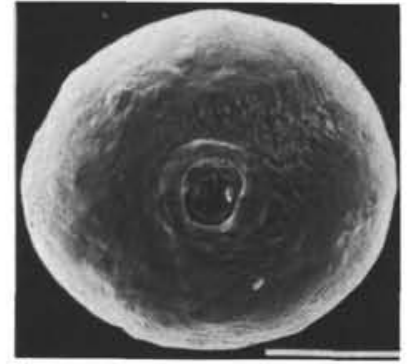

5

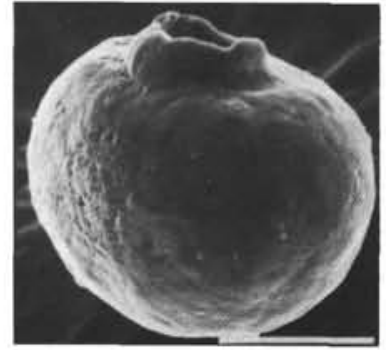

9

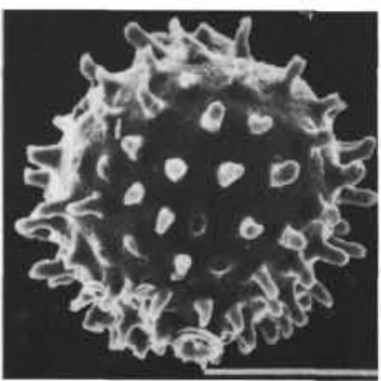

13

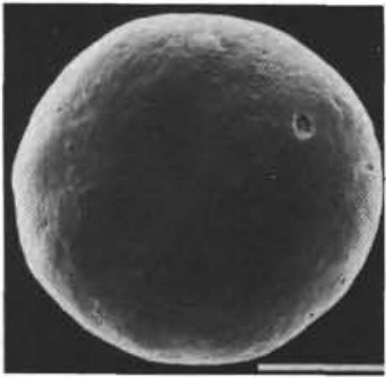

6

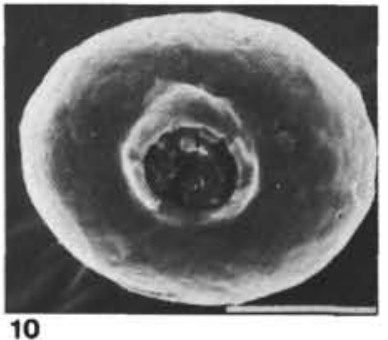

10

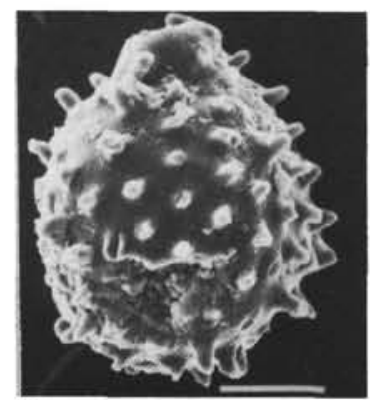

14

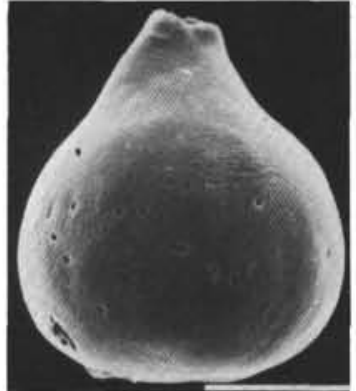

3

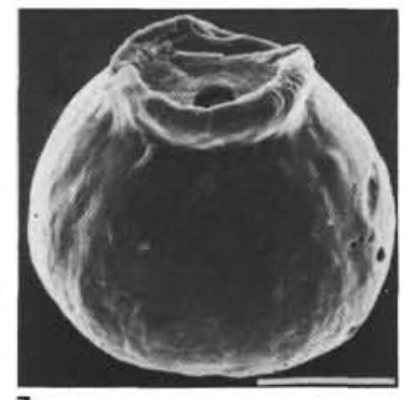

7

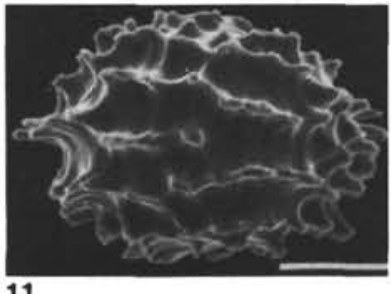

11

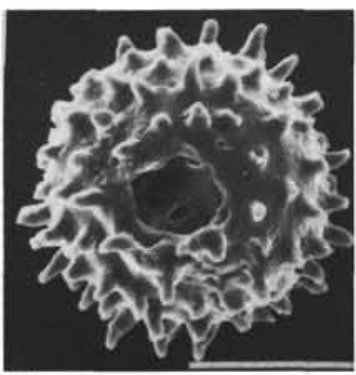

15

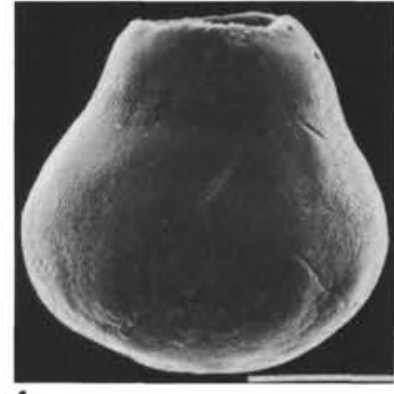

4

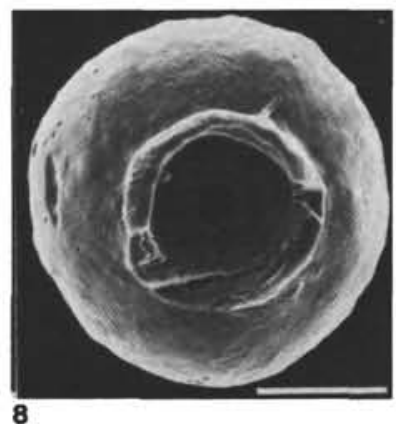

8

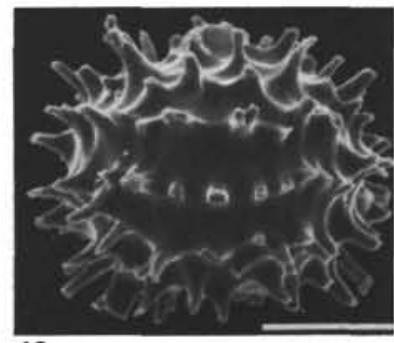

12

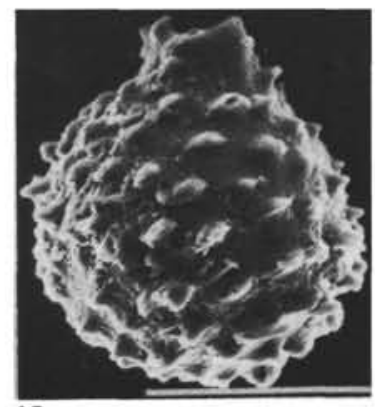

16

Plate 1. (Scale bar $=50 \mu \mathrm{m}$.) 1. B. laevis Daniels and Spiegler, lateral view; monocamerate, flattened aboral surface; DSDP 604-26-2, 104-108 $\mathrm{cm}$; upper Miocene. 2. B. laevis, lateral view; monocamerate, subspherical, short neck; DSDP 604-26-2, 104-108 cm; upper Miocene. 3. B. laevis, lateral view; monocamerate, spherical, long neck; DSDP 604-26-2, 104-108 cm; upper Miocene. 4. B. laevis, lateral view; bicamerate, smaller upper chamber less spherical and partly broken off; DSDP 604-26-2, 104-108 cm; upper Miocene. 5. B. laevis, oral view; monocamerate, subcircular outline, eroded test shows edges of tabular calcite laths; note thin calcite plate near base of apertural opening (compare with Figs. 7, 8); DSDP 604-26-2, 104-108 cm; upper Miocene. 6. B. laevis, aboral view; monocamerate, circular outline; DSDP 604-26-2, 104-108 cm; upper Miocene. 7. B. laevis, oblique view; bicamerate, smaller chamber broken away revealing thin calcite plate containing central pore, which separates two chambers (compare with Figs. 5, 8); DSDP 604-26-2, 104-108 cm; upper Miocene. 8. B. laevis, oral view, (same specimen as Fig. 7); bicamerate, circular outline; calcareous plate containing central pore separates two chambers of unequal diameter; DSDP 604-26-2, 104-108, upper Miocene. 9. B. laevis, lateral view; monocamerate, subspherical; Forest Hill Fm., Wayne Co., Miss.; lower Oligocene. 10. B. laevis, oral view; monocamerate, ovate outline, chamber filled with sediment; Forest Hill Fm., Wayne Co., Miss., lower Oligocene. 11. Bolboforma sp., lateral view; monocamerate, spines arranged in subhorizontal rows, having faint vertical ridges between rows; DSDP 604-26-2, 119-121 cm; upper Miocene. 12. Bolboforma sp., lateral view; similar to Fig. 11; DSDP 604-26-2, 55-59 cm; upper Miocene. 13. B. spinosa Daniels and Spiegler, lateral view; monocamerate, spherical, widely spaced short spines; DSDP 61-19-6, 120-124 cm; upper Eocene. 14. B. spinosa, lateral view; monocamerate, subspherical, widely spaced short spines; COST B-3 well; 5010-5040 ft, below rig floor; upper Eocene. 15 . B. spinosa, oral view; monocamerate, circular outline, aperture partly broken away, widely spaced short spines; ASP 22; 36-4.2 in.; lower Oligocene. 16. B. spinosa, lateral view; monocamerate, spherical, widely spaced short spines; basal Calvert Fm., Haynesville, Va., Borehole, $262 \mathrm{ft} .10$ in.; middle Miocene. 


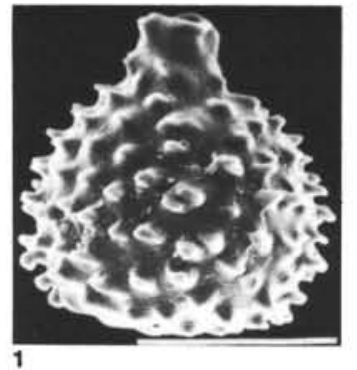

1
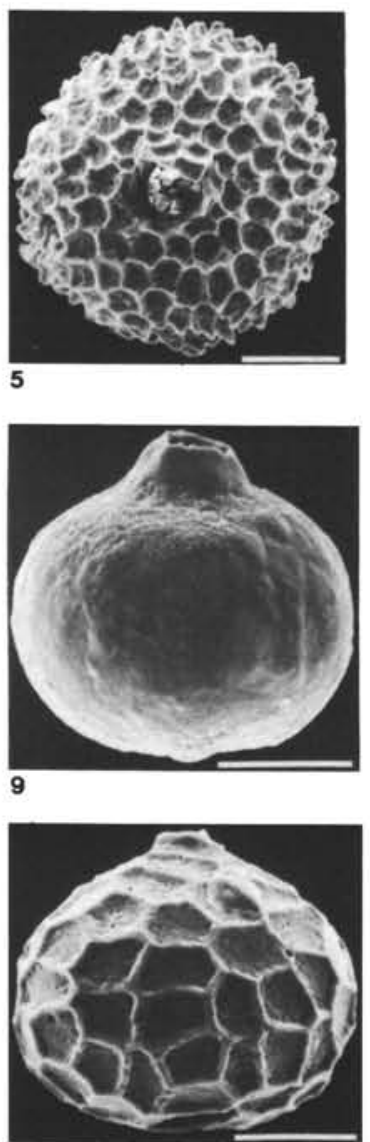

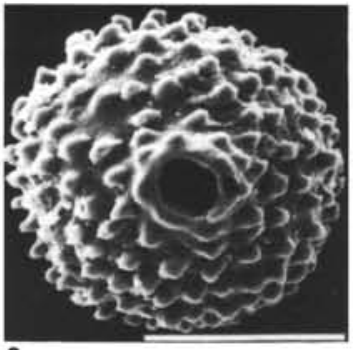

2

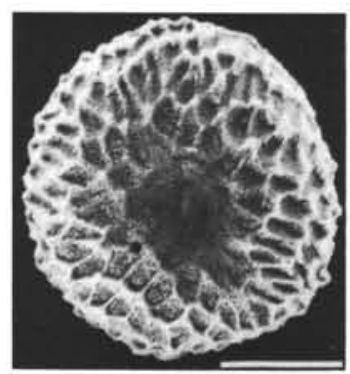

6
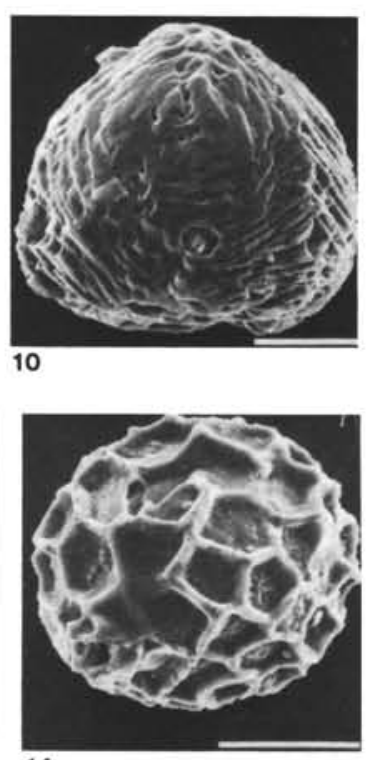

14
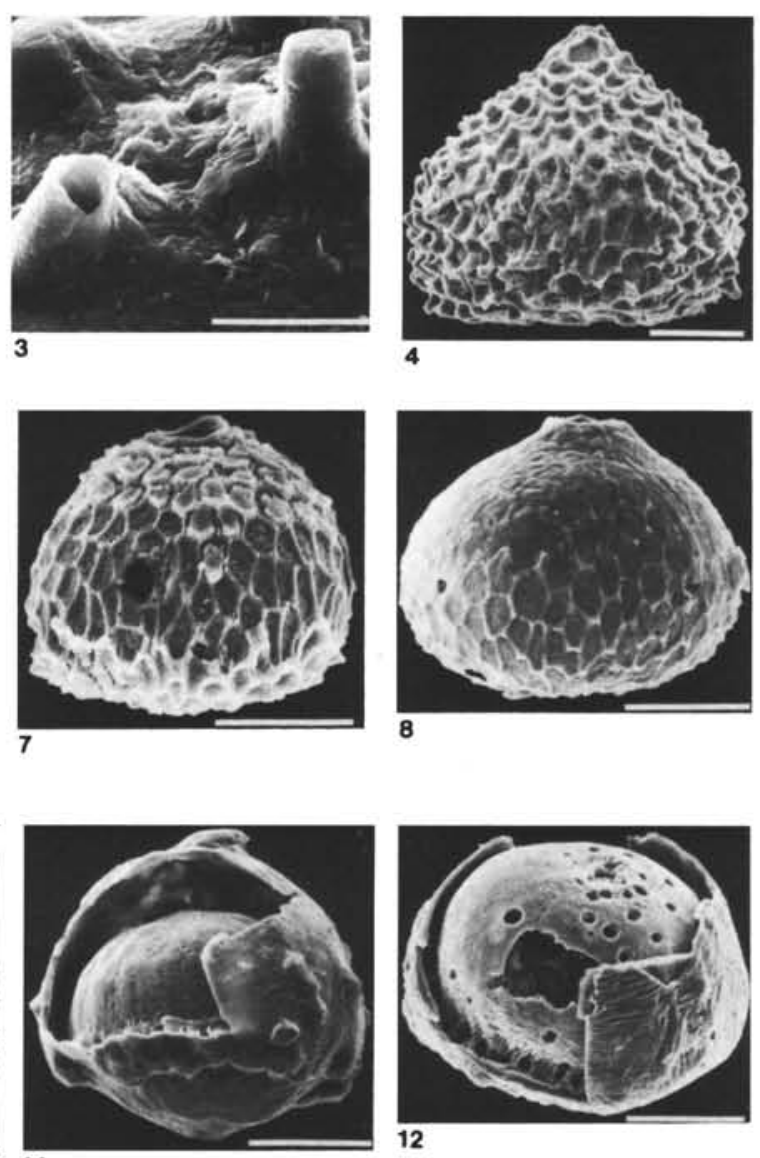

11

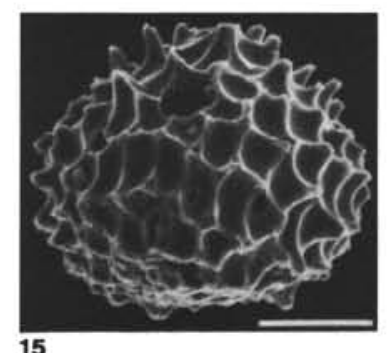

15
8
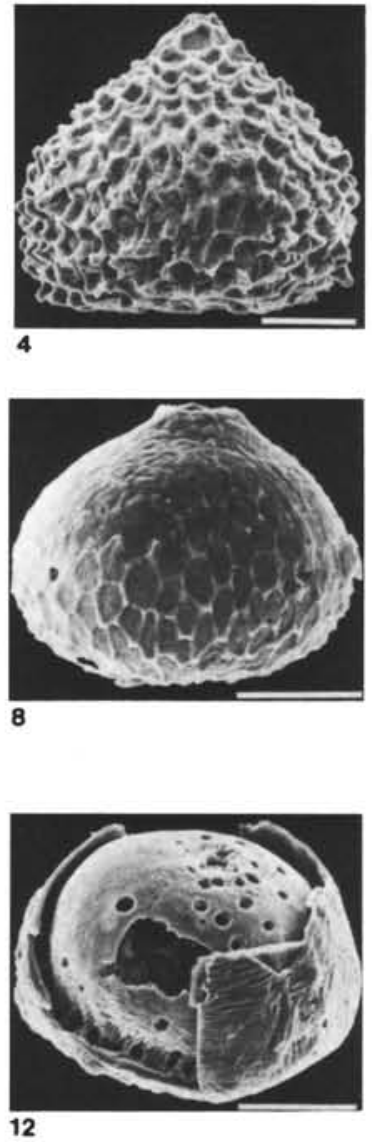

4

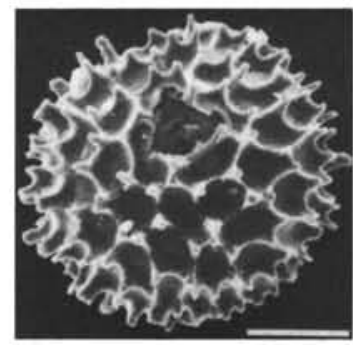

16

Plate 2. (Scale bar $=50 \mu \mathrm{m}$ unless specified otherwise.) 1. B. spinosa Daniels and Spiegler, lateral view; monocamerate, flattened aboral surface, widely spaced short spines, long neck; Haynesville, Va., borehole, $262 \mathrm{ft}$., $10 \mathrm{in}$.; basal Calvert Fm.; middle Miocene. 2. B. spinosa, oral view; monocamerate, circular outline; widely spaced short spines; Haynesville, Va., borehole, $262 \mathrm{ft}$., $10 \mathrm{in}$.; basal Calvert Fm.; middle Miocene. 3. B. spinosa, enlargement of exterior surface; hollow base of spine at left; DSDP 612-18-3, 120-124 cm; upper Eocene; scale bar $=10 \mu \mathrm{m}$. $\quad 4 . B$. metzmacheri (Clodius), lateral view; monocamerate, flattened aboral surface, fine polygonal reticulations elongated vertically, short spines at intersections of reticulae; DSDP 604-26-2, 119-121 cm; upper Miocene. 5. B. metzmacheri, oral view; monocamerate, circular outline, lower side of neck broken away, fine polygonal reticulations elongated vertically, short spines at intersections of reticulae; DSDP 604-26-2, 55-59 cm; upper Miocene. 6. B. metzmacheri, aboral view; monocamerate, circular outline, elongate polygonal reticulae absent at center, outer layer of calcite partly dissolved leaving spongy texture of small crystallites; DSDP 604-26-2, 119-121 cm; upper Miocene. 7. B. metzmacheri, lateral view; monocamerate, slightly flattened aboral surface; differential dissolution shows at least three calcite layers in complex wall; note spongy texture of middle layer; third (inner) layer visible at right side of large puncture; DSDP 604-26-2, 119-121 cm; upper Miocene. 8. B. metzmacheri, lateral view; cepoid outline, further dissolution (cf. Fig. 7) has removed spongy middle layer of calcite from upper part of test, but spongy middle layer with subdued reticulations remains on lower half of test; DSDP 604-26-2,119-121 cm; upper Miocene. 9. B. laevis? or B. metzmacheri? lateral view; monocamerate, subspherical; resembles typical $B$. laevis, but retains faint imprint of elongate polygonal reticulations, which suggests this may be late stage in dissolution of B. metzmacheri; DSDP 546-15,CC; upper Miocene. 10. Bolboforma sp., lateral view; bullet shaped, bicamerate, second chamber envelopes first (cf. Figs. 11, 12); outer surface severely dissolved revealing peculiar pattern of multiple adjacent whorls of tabular calcite laths; DSDP 106B-4-3, 23-25 cm; middle Miocene. 11. Bolboforma sp., lateral view; bullet shaped, bicamerate; wall of second chamber broken away revealing smaller first chamber inside; DSDP 106B-4-3, 23-25 cm, middle Miocene. 12. Bolboforma sp., oblique view; bullet shaped, bicamerate; most of second chamber broken away revealing smaller first chamber inside; dissolution reveals whorls of calcite laths in walls of both chambers; DSDP 106B-4-3, 23-25 cm; middle Miocene. 13. B. reticulata Daniels and Spiegler, lateral view; monocamerate, subspherical, coarse polygonal reticulations; DSDP 106B-5,CC; middle Miocene. 14. B. reticulata, oblique view; monocamerate, circular outline, coarse polygonal reticulations; DSDP $612-16-7,22-26 \mathrm{~cm}$; lower Oligocene. 15. B. badenensis Szczechura, lateral view; monocamerate, subspherical, coarse reticulations with short spines at intersections of reticulae; DSDP 604-26-2, 119-121 cm; upper Miocene. 16. B. badenensis, diagonal view; spherical, monocamerate; well-developed spines at intersections of polygonal reticulae; COST B-3 well; $4620-4650 \mathrm{ft}$. below drill floor; lower Miocene. 


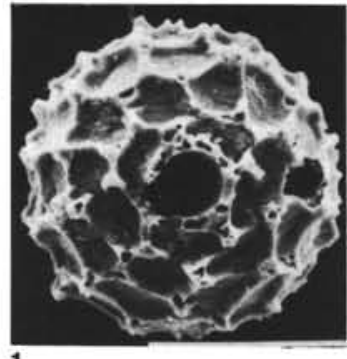

1

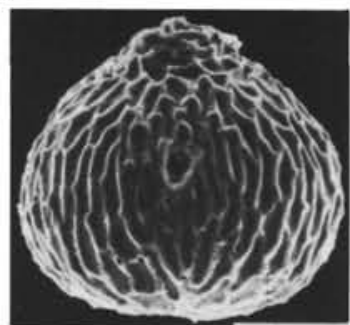

5

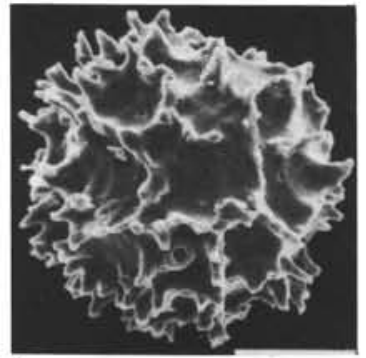

9

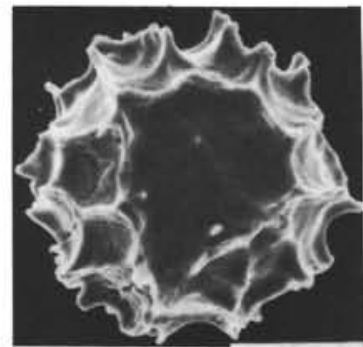

13
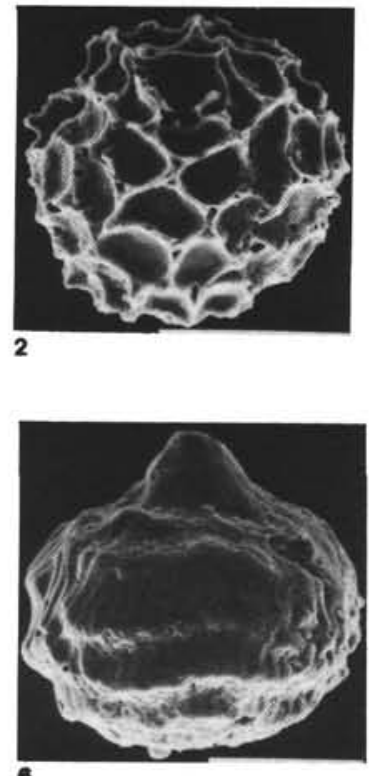

6

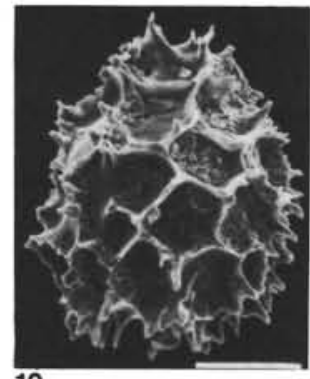

10

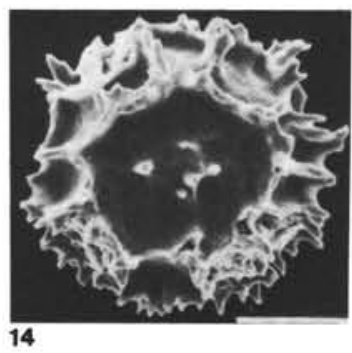

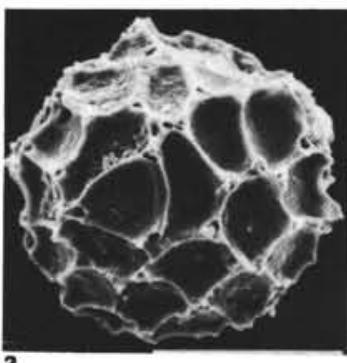

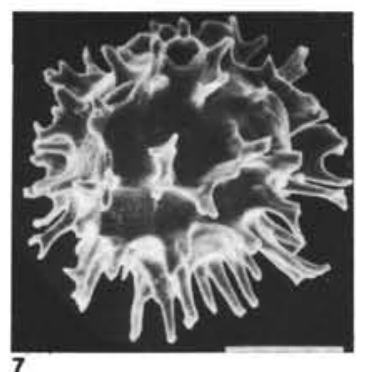

7

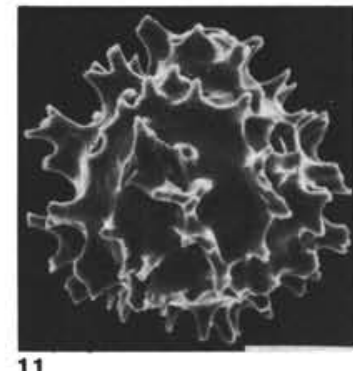

11

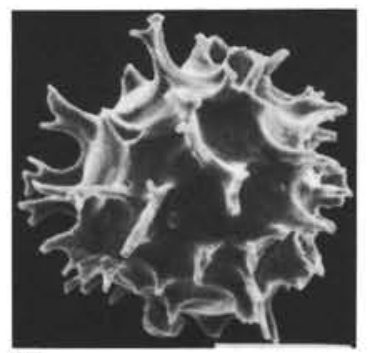

15
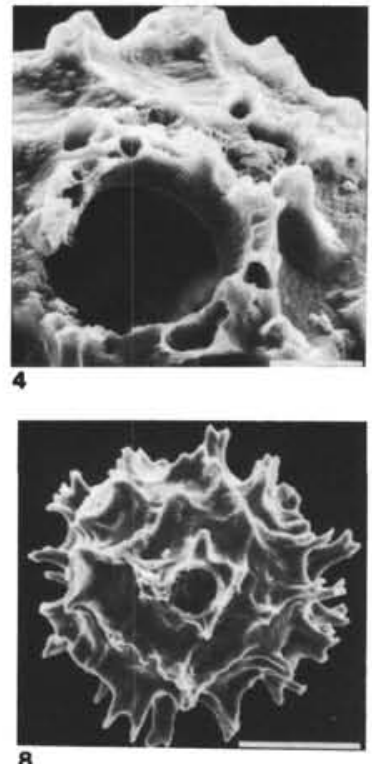

8

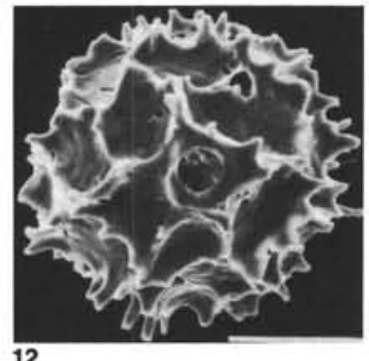

12

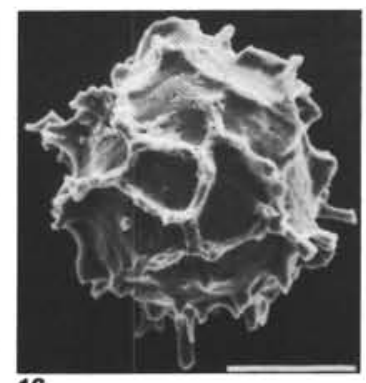

16

Plate 3. (Scale bar $=50 \mu \mathrm{m}$ unless specified otherwise.) 1. B. badenensis Szczechura, oral view; circular outline, monocamerate, outer calcite layer partly eroded revealing hollow spines and two-layered microstructure of neck; Haynesville, Va., borehole, $173 \mathrm{ft}$.; basal Choptank Fm.; middle Miocene. 2. B. badenensis, oblique view; characteristics similar to Fig. 1; Haynesville, Va., borehole; basal Choptank Fm.; middle Miocene. 3. B. badenensis, aboral view; monocamerate, circular outline; calcite dissolution reveals hollow spines and reticulae; Haynesville, Va., borehole; $173 \mathrm{ft}$.; basal Choptank Fm.; middle Miocene. 4. B. badenensis, enlargement of apertural region; calcite dissolution reveals hollow spines and two layers of the neck; oral calcite plate mostly dissolved; same specimen as Fig. 1; scale bar $=10 \mu \mathrm{m}$. $\mathbf{5}$. Bolboforma sp., lateral view; cepoid, monocamerate, fine reticulations extremely elongate in vertical plane; DSDP 604-26-2, 104-108 cm; upper Miocene. 6. Bolboforma sp., lateral view; monocamerate, subspherical, partly dissolved surface shows subdued horizontal ridges connected by closely-spaced short vertical ridges; Haynesville, Va., borehole; 269 ft.; Old Church Fm.; upper Oligocene? 7. B. irregularis Daniels and Spiegler, oblique view; monocamerate, spherical, coarse polygonal reticulations with elongate, often bifurcate, spines at intersections and at irregular positions between intersections of reticulae; spines often connected by thin calcite membrane; ASP 15-7, 3.8 in.; lower Oligocene. 8. B. irregularis, oral view; monocamerate, spherical, several pairs of spines are connected by calcite membrane to form broad bifurcate "paddles"; DSDP 612-16-3, 117$121 \mathrm{~cm}$; lower Oligocene. 9. B. irregularis, aboral view; monocamerate, spherical; note irregular spacing of spines along polygonal reticulae; DSDP 612-17-6, 120-124 cm; upper Eocene. 10. B. irregularis, lateral view; ovate outline, monocamerate; DSDP 612-17-6, 120-124 cm; upper Eocene. 11. B. irregularis, lateral view; monocamerate, spherical, broad neck; note groups of two or three spines joined by thin calcite membrane to form broad "paddles"; DSDP 604-26-2, 119-121 cm; upper Miocene. 12. B. irregularis, oral view; monocamerate, spherical; most spines broken or partly dissolved; DSDP 604-26-2, 104-108 cm; upper Miocene. 13. B. irregularis, aboral view; monocamerate, spherical; note broad polygonal aboral surface is free of reticulations and spines; DSDP 604-26-2, 104-108 cm; upper Miocene. 14. B. irregularis, aboral view; monocamerate, spherical, broad polygonal aboral surface contains a few short spines; ASP 15-7, 3.8 in.; lower Oligocene. 15. B. irregularis, lateral view; monocamerate, spherical; note clumps of two and three spines connected by thin calcite membranes; also note irregular development of polygonal reticulae; DSDP 612-16-2,117-121 cm; lower Oligocene. 16. B. irregularis, lateral view; monocamerate, spherical; note irregular size and shape of polygonal reticulae; most spines broken or dissolved; DSDP 612-16-6, 117-121 cm; lower Oligocene. 

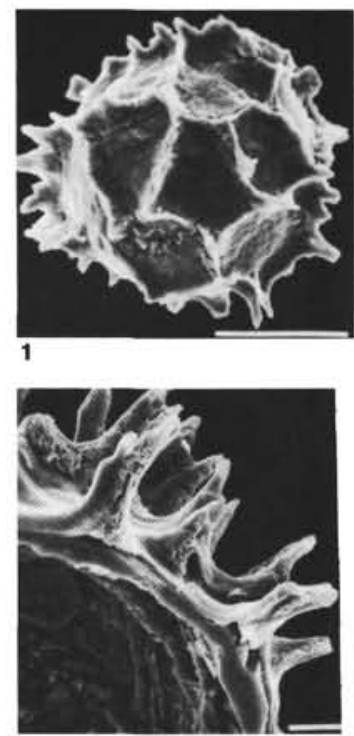

5

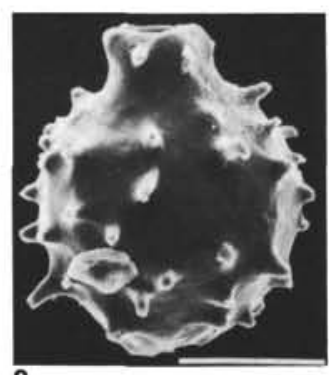

9

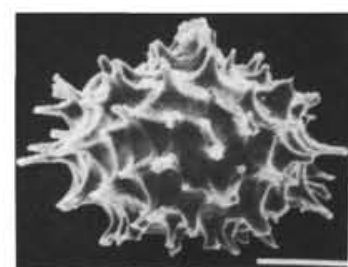

13

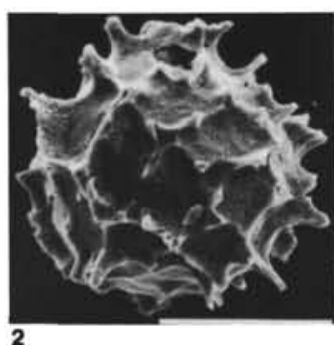

2

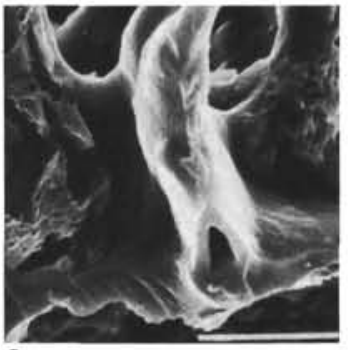

6

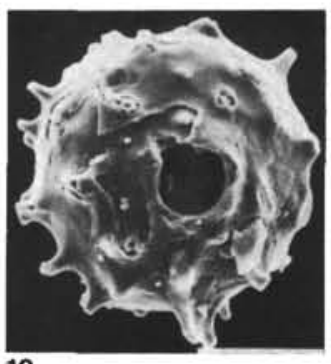

10

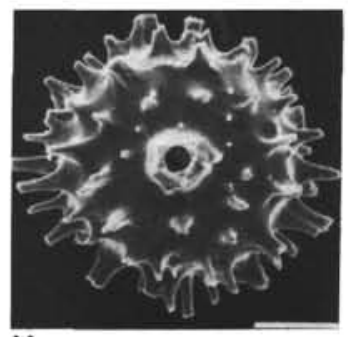

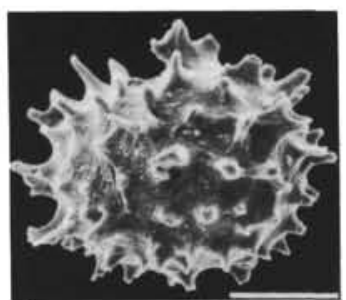

3

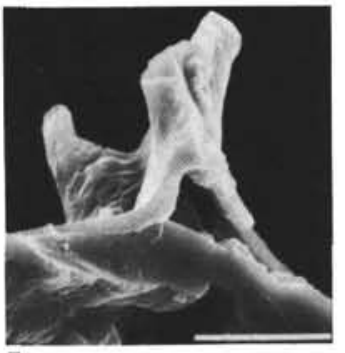

7

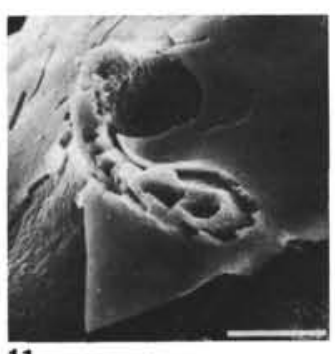

11

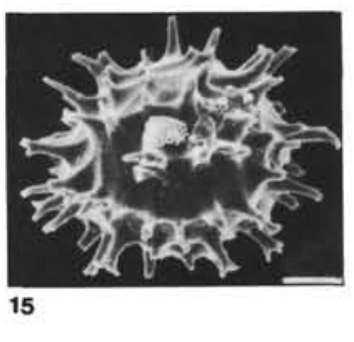

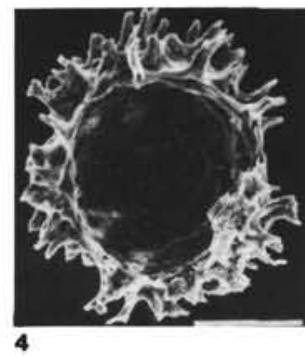

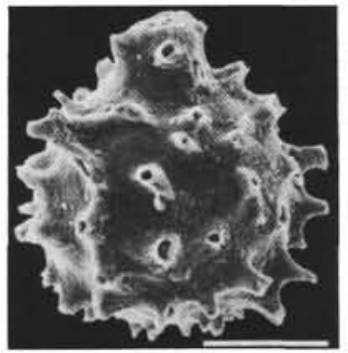

8

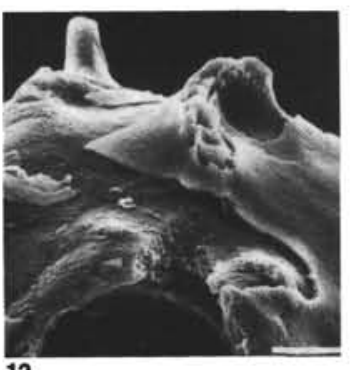

12

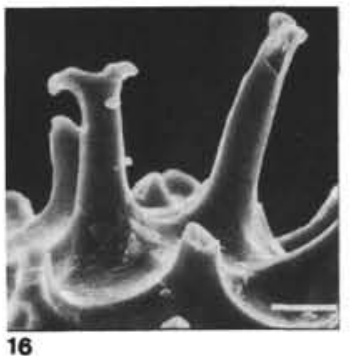

Plate 4. (Scale bar $=50 \mu \mathrm{m}$ unless specified otherwise.) $\quad$ 1. B. irregularis Daniels and Spiegler, oblique view; monocamerate, spherical; outer layer of calcite and most spines partly dissolved; DSDP 604-26-2, 104-108 cm; upper Miocene. 2. B. irregularis, lateral view; monocamerate, spherical; note irregular development of polygonal reticulae and spines; surface largely covered by thin layer of very fine grained calcareous sedimentary matrix; Haynesville, Va., borehole; $269 \mathrm{ft}$.; Old Church Fm.; upper Oligocene? 3. B. irregularis, lateral view; monocamerate, subspherical; surface partly dissolved, a few paddlelike groups of spines visible, reticulations subdued; Hiwannee Station, Miss.; Red Bluff Fm., type locality; lower Oligocene. 4. B. irregularis, section view; monocamerate, spherical; side of chamber wall broken away revealing hollow interior and layered microstructure of wall and ornamentation (see Figs. 5-7); DSDP 612-16-6, 58-62 cm; lower Oligocene. 5. B. irregularis, enlargement of part of Fig. 4; note two layers of test wall (inner one dissolved; middle one thick, not spongy; outer one thin, forming reticulae and spines); note hollow spaces separating two layers at base of spines and reticulae; scale bar $=10 \mu \mathrm{m}$. 6 . B. irregularis, enlargement of part of Fig. 4; note that spinose reticulum is hollow and formed by thin outer calcite layer; scale bar $=10 \mu \mathrm{m}$. $7 . B$. irregularis, enlargement of part of Fig. 4; note spinose hollow reticulum formed by thin outer calcite layer; hollow space separates thin-walled reticulum from thick middle layer; scale bar $=10 \mu \mathrm{m} . \quad 8$. B. irregularis, lateral view; monocamerate, spherical; surface partly dissolved showing hollow spine bases and spongy texture of calcite layer; Hiwannee Station, Miss.; Red Bluff Fm., type locality; lower Oligocene. 9. B. irregularis, lateral view; monocamerate, subspherical; spines and reticulae subdued by calcite dissolution; Wayne Co., Miss.; Forest Hill Fm.; lower Oligocene. 10 . B. irregularis, oral view; monocamerate, spherical; test partly dissolved showing layered structure and hollow spine bases (see Figs. 11, 12); Wayne Co., Miss.; Forest Hill Fm.; lower Oligocene. 11. B. irregularis, enlargement of part of Fig. 10; note two layers of test wall and hollow spine bases; reticulum is formed from several aligned spines; scale bar $=10 \mu \mathrm{m}$. 12. B. irregularis, enlargement of part of Fig. 10; note thin outer calcite layer, thick spongy middle layer and thin inner layer forming inner surface of tubular neck; scale bar $=10 \mu \mathrm{m}$. 13 . B. pseudohystrix Müller and Spiegler, lateral view; monocamerate, compressed spherical; widely-spaced spines broad and ridged at base, tapering quickly to narrow extensions that often are bifurcate and hooked (see Fig. 16); ridges along base of spines cross surfaces between spines to form subdued symmetrical reticulations; ASP 15-5, 1.8 in.; lower Miocene. 14. B. pseudohystrix, oral view; monocamerate, circular outline; note symmetrical arrangement and wide spacing of spines; one spine at upper left is broken revealing hollow interior; ASP 15-5, 1.8 in.; lower Miocene. 15 . B. pseudohystrix, oblique view; compressed spherical; well preserved specimens displaying several bifurcate, hooked spines (see Fig. 16); ASP 15-3, 3.4 in.; middle Miocene. 16. B. pseudohystrix, enlargement of spines; note the ridges along base of spines cross surface between spines to form subdued reticulation; one spine shows typical hooked bifurcation; ASP 15-3, 3.4 in.; middle Miocene; scale bar $=10 \mu \mathrm{m}$. 